DOI https://doi.org/10.36059/978-966-397-225-1-11

\title{
RETHINKING THE ART MUSEUM \\ IN SOCIAL AND CULTURAL DIMENSION
}

\section{Goncharova Olena}

\section{INTRODUCTION}

From the very beginning, the art museum as a social and cultural institution was perceived in terms of dominant ideological and philosophical paradigms of a specific historical and cultural era. The rethinking the art museum regarding its social role and purpose was determined by the external intellectual and political environment, according to dominant ideological and philosophical discourse.

Now, in the absence of unified narrative about art museums, they determine the rhetoric of their own presentation "urbi et orbi". This task became particularly important in the context of a globalizing market for museum services. In addition, in recent decades, art museums have competed with "themselves", making their collections widely available due to their electronic versions.

This put art museums in a fundamentally new situation, when it became impossible to rely only on the traditional motivation for visiting museum. The classical functions, such as collecting, storing, and exhibiting are not sufficient to ensure competitiveness and maintain social interest. This is especially important for those museums that fully or largely fund their budget with their own efforts.

The dramatic changes in the cultural situation in which art museums find themselves now find theoretical comprehension in the works of museological theorists, museum specialists and representatives of other fields of activity related to museum practices.

Thus, in 2010, a book by the American museologist N. Simon was published, in which the concept of "participatory museum" was used. The narrative of Participatory Museum was based on the analogy with communication that is typical for social networks. ${ }^{1}$

\footnotetext{
${ }^{1}$ Simon N. (2010) The Participatory Museum. Santa Crus: Museum 2.0.
} 
Unlike authors who focused on virtual communication of museums, such as J.T. Grabill, S. Pigg and K. Wittenauer, ${ }^{2}$ N. Simon included live communication in the concept of Participatory Museum, citing several modern examples in her book.

The new phrase quickly came into museum discourse, and its conceptual content began to be actively developed by museologists.

The results of such developments are published in the multi-authored monographs of American researchers "Participatory Culture: Museum as a Forum for Dialogue and Collaboration"3 and Russian authors "Museum as a Forum for Education: Game, Dialogue, Participatory Culture". 4

Another aspect of modern museum discourse was articulated by Denis Belkevich in the publication "Museum in Search of an Audience". Analyzing the museum practices of leading art museums, he introduces the concept of edutainment: "education as pleasure". This conclusion was made by the author based on the analysis of data from marketing research conducted concerning the motivation of art museum visitors. ${ }^{5}$

The cultural practices of European and American art museums with children's and teenage audiences, including in terms of their verbal presentation, were covered in articles by O. M. Goncharova. ${ }^{67}$

According to John H. Falk, Lynn D. Dierking and Marianna Adams, authors of the section "Living in a Learning Society: Museums and Free-choice

${ }^{2}$ Grabill J.T., Pigg S., Wittenauer K. (2009) Take Two: A Study of the Co-Creation of Knowledge on Museum 2.0 Sites. Proceedings of the Museums and the Web 2009: the international conference for culture and heritage online. (April 15-18, 2009). http://www.museumsandtheweb.com/mw2009/papers/grabill/grabill.html (accessed 5 December 2020).

3 Agapova D. (ed.) (2015) Kul'tura uchastiya: muzey kak prostranstvo dialoga $i$ sotrudnichestva [Participatory Culture: Museum as a Forum for Dialogue and Collaboration] (electronic book). St. Petersburg, p. 36. http://kizhi.karelia.ru/media/info/files/attached/1601/kultura_uchastiya_muzej_kak_prost ranstvo_dialoga_i_sotrudnichestva.pdf (accessed 5 December 2020)

${ }^{4}$ Kopelyanskaya N. (comps.) (2015) Muzey kak prostranstvo obrazovaniya: igra, dialog, kul'tura uchastiya [Museum as a space of education: game, dialogue, culture of participation] (2nd ed). Moscow: Muzeinye resheniia, p. 138.

5 Bel'kevich D. (2012) Muzey v poiskakh auditorii [Museum in search of an audience.]. Iskusstvo [Art] (electronic journal), no. 2(581). Retrieved from: http://iskusstvo-info.ru/muzej-v-poiskah-auditorii/ (accessed 5 December 2020).

${ }^{6}$ Goncharova O. M. (2018) Kulturni praktyky dlia ditei u khudozhnikh muzeiakh SShA [Cultural practices for children in the USA Art Museums]. National Academy of Managerial Staff of Culture and Arts Herald, no. 1, pp. 16-20.

${ }^{7}$ Goncharova O. M. (2018) Kulturni praktyky dlia ditei u khudozhnikh muzeiakh SShA [Cultural practices for children in the USA Art Museums]. National Academy of Managerial Staff of Culture and Arts Herald, no. 1, pp. 16-20. 
Learning" in the book "A Companion to Museum Studies", although constructivist learning ideas have been spreading in academic community for quite a long time, the behaviorist learning model continues to flourish in museums... Many museums, consciously or unconsciously, work properly, adjusting the lighting and creating the right labels, but some of them exhibit museum objects "with no strings attached"... However, the constructivist model understands learning as a contextual process. Prior knowledge, experience, interests and all motives consist of a personal context that is embedded in a complex of social and cultural and physical context ... in time and space. ${ }^{8}$ More typical is education of visitors in two parallel ways: (a) through study of global ideas; (b) study of specific, but usually idiosyncratic facts and concepts ... Recent research (Falk and Storksdieck 2005) helped to demonstrate how complex learning processes and results are in museums. ${ }^{9}$

One of the most recent publications - article by museologists Jessica J. Luke, Susan M. Letourneau, Nicole R. Rivera, Lisa Brahms and Sarah May - is devoted to the application of game practices in museum work with children, but specialized children's museums were the subject of their research. ${ }^{10}$

As Eilean Hooper-Greenhill writes in the study "Changing Values in the Art Museums: Rethinking Communication and Learning", the development of new narrative in art museums requires new ways of thinking about collections and audiences, new ways of their integration based on a combination of knowledge, power, identity and language. ${ }^{11}$

According to T. Kubasova, the interactive expositions allowing visitors to involve all their senses in the process of cognition have become more and more popular in recent years. The museums overcome the barrier of "inaccessibility", become closer and clearer. The informal learning through emotional involvement relieves stress before solving complex tasks, and the

${ }^{8}$ Falk J. H., Dierking L. D., Adams M. (2006) Living in a learning society: museums and free-choice learning. A Companion to Museum Studies (ed. Macdonald S.). Padstow: Blackwell Publishing, p. 325.

${ }^{9}$ Falk J. H., Dierking L. D., Adams M. (2006) Living in a learning society: museums and free-choice learning. A Companion to Museum Studies (ed. Macdonald S.). Padstow: Blackwell Publishing, p. 329.

${ }^{10}$ Luke J. J., Letourneau S. M., Rivera N. R., Brahms L., May S. (2017) Play and Children's Museums: A Path Forward or a Point of Tension? Curator the Museum Journal, vol. 60 , no. 1, pp. 37-46.

${ }^{11}$ Hooper-Greenhill E. (2012) Changing values in the Art Museums: Rethinking communication and learning (ed. Carbonell B. M.). Museum Studies: An Anthology of Contexts (2nd ed, pp. 517-532). Malden: Blackwell Publishing. 
joy of victory encourages new achievements - museum becomes a new space of education. ${ }^{12}$

Despite these and other publications devoted to study of museum sphere, specifics of modern cultural situation in which art museums work, the issue of rhetoric of art museum presentation and self-presentation that is formed in the social and cultural discourse and evolves with its paradigm changes remains unaddressed.

Purpose of monograph section: to investigate changes in rethinking the art museum as an object of social and cultural discourse of modern era and to identify features of rhetoric of art museum as a subject of social and cultural discourse in modern globalized culture.

To achieve this goal, a range of historical and cultural, social and philosophical methods based on a systematic approach was used.

The historical and cultural analysis of changes in rethinking the art museum as an object of social and cultural dimension from the Age of Enlightenment to the rhetoric of art museum as a subject of social and cultural dimension in modern globalized culture.

\section{Rethinking the Art Museum as an Object of Social and Cultural Dimension}

The public museum is the brainchild of the Age of Enlightenment (XVIII). Developing the ideas of rationalism, the ideologists of the Age of Enlightenment considered mind as a cure-all for social evil and a means of achieving social peace.

A significant factor in spreading relevant intellectual fashion among upper classes was obviously the praise by the intellectual elite, producer of enlightenment ideology, of those officials who shared their ideas regarding the enlightenment project.

The essay by the German philosopher I. Kant "Answering the Question: What Is Enlightenment?" (1784) is eloquent example in this regard. I. Kant wrote about the "enlightened sovereign": "... such a sovereign ... deserves to be praised by grateful contemporaries and their descendants as a statesman" who "gave everyone the freedom to use their own minds in matters of conscience ..."."

The Enlightenment ideas were captured by many representatives of the European aristocracy. Some of them under influence of this ideology began

${ }^{12}$ Kopelyanskaya N. (comps.) (2015) Muzey kak prostranstvo obrazovaniya: igra, dialog, kul'tura uchastiya [Museum as a space of education: game, dialogue, culture of participation] (2nd ed). Moscow: Muzeinye resheniia, p. 138.

${ }^{13}$ Kant I. (1966) Sochineniya [Essays] (Vol. 6). Moscow: Mysl'. 
to open their collections, including artistic works, first antiques, and later collection of paintings.

However, the idea of art education dates back to XVI century, when in 1562 the art collection aiming at giving the students the opportunity to meet and copy this artistic works were formed at the world's first art academy Florence Academy of Art.

In 1620, Federico Borromeo, cardinal and Archbishop of Milan, opened the Academy of Art in Milan that he merged with Pinakothek founded two years earlier. The basis of Pinakothek was the private collection of the Archbishop himself, which he opened for public access in 1609. This collection consisted of more than 250 paintings, sculptures and drawings by Italian artists.

Unlike private art collections, which in addition to their aesthetic function served as a status presentation of their owner, galleries (pinakothekes) at the Academies of Art from the very beginning were intended for training of future artists and sculptor, so access to them was limited to artists and their students.

The transition from educational to enlightenment function of art collections took place with introduction of practice of increasing access to art collections.

Again, the first people to take such steps were the church ministers.

Thus, in 1734, Pope Clement XII opened to the public the collections of the Capitoline Antiques in Rome, becoming the basis of the Capitoline Museums (Some people generally trace the beginning of the Capitoline Museums to the collection of bronze sculptures of ancient times presented by Pope Sixtus IV to residents of capital in 1471).

The Enlightenment ideology initiated the transfer of private collections to state or city ownership, and where this did not happen, prompted the establishment of museums as public institutions.

Uffizi is one of the first public art museums. Uffizi became the property of city of Florence in 1743, according to the will of Anna Maria Luisa de' Medici, the last Medici heiress. The will was made according to Agreement concluded between Anna Maria Luisa de' Medici and Duke of Lorraine in 1737, known as the "Family Pact". According to this Agreement, the Medici art collections were handed over to the new Grand-duke on condition that they should remain "forever" bound to the city of Florence. In addition, the authorities of Florence undertook to ensure that the collection remained at the same place where its formation began. ${ }^{14}$

${ }^{14}$ Fossi G. (2017) Galereya Uffitsi. Ikusstvo, istoriya, kollektsii [Uffizi Gallery. Art, history, collections]. Florence: Giunti Editore, p. 14. 
In 1769, Uffizi was opened to the public by Peter Leopold II, Grand Duke of Tuscany, Archduke of Austria and future Holy Roman Emperor.

In 1781 in Vienna, the Imperial Gallery was opened to the public in the Upper Belvedere. In the future, this gallery for a long time served as a model for organizing a public art museum.

In 1750 in Paris, homeland of the French Enlightenment, the Luxembourg Palace with its artistic treasures was opened to the public twice a week.

However, the Royal court, as well as the aristocracy in general, was in no hurry to open their art collections for the "third estate". The Louvre became a public museum already during the French Revolution. On May 6, 1791, the Constitutional Assembly officially proclaimed the creation of museum of art in the Louvre. During 1792, the nationalized royal art collection was moved to the Louvre, which was opened to the public on August 10, 1793 as the Republican Museum of Art. The museum was open to the public three days a week. In 1796, the museum in the Louvre was renamed the Central Museum of Art, and in 1803 - Museum of Napoleon. Under this name the museum existed by $1814 .^{15}$

However, creation of regional art museums in France was very slow. This process was accelerated by order of Napoleon. For this purpose, decree was issued by J.-A. Chaptal on September 01, 1801 (since 1781 he has been a Minister of Internal Affairs of the government during the First Republic and Consulate of Napoleon Bonaparte). According to this decree, 15 regional art museums were established in Nantes, Bordeaux, Lille, Lyon, Rouen, Strasbourg, and others. The paintings from Central Museum of Art in Paris were transferred to newly established museums.

The heads of German states was also in no hurry to open their art collections, much less transfer them to public use.

So, until the second half of the XVIII century, the Royal Gallery in Dresden (now the Gallery of Old Masters) could only be visited by a select few: court nobility and individuals who received permission. For example, the German art historian J. Winckelmann came to the Gallery as the librarian to Count Heinrich von Bünau, with recommendations from the royal confessor Leo Rauch, who was a friend of director of the Royal Gallery Johann Gottfried Riedel. As noted by J. Winckelmann, "demonstrating a world of masterpieces

${ }^{15}$ Louvre (2012) Ves' Luvr. Shedevry, istoriya dvortsa, arkhitektura [All the Louvre. Masterpieces, the history of the palace, the architecture]. Paris: Beaux Arts Editions, pp. 24-25. 
from Italy and other countries that aim to cultivate good taste is a true monument to the greatness of the monarch (August III)". ${ }^{\prime 6}$

It was very difficult to get into the Dresden Gallery even at the beginning of the XIX century. It was emphasized that the "Royal Gallery is not an open public collection".

In 1802, the Gallery was visited by brothers Friedrich and Wilhelm Schlegel, German philosophers, founders of Romanticism, who admired Winckelmann's idea of the greatness of ancient culture. The gallery attracted by the fact that it gave an opportunity to clearly see the masterpieces of antiques.

Only after adoption of the Constitution of Saxony in 1831, which promoted a certain democratization of the country, it was easier for the population to visit the Gallery. On August 16, 1838, Bernhard Lindenau, cabinet minister, as General Director of the "Royal Art and Scientific Meetings" issued a decree by which from that day and until the end of October 1838, excluding weekends and holidays, the Gallery was opened daily from 9:00 AM to 1:00 PM for free access, but only for the "properly dressed public".

Only in the middle of the XIX century the process of opening art collections and turning them into public museums has become widespread.

During the considered period of the XVIII-XIX centuries, two concepts of museum were formed. The first one corresponded to the Enlightenment ideology and considered museum as an institution in the system of mass education. In the discourse of the Enlightenment, the main task of the art museum was to serve the ideals of enlightenment.

However, after the end of era of Napoleon, who acting quite in line with the enlightenment paradigm (despite the ambiguity of many of his reforms) did a lot for the development of art museums in France, the perception of art museum as a social institution changed.

The Enlightenment was replaced by Romanticism.

The discourse of Romanticism concerning art museum was determined by the exceptional role of the art. The Romantics relied on G. Hegel's philosophy, in which the art was declared the form of absolute spirit - the highest level of absolute idea development.

Hegel wrote that art "is a specific contemplation and representation of the absolute spirit as an ideal ...... this is a form of beauty". ${ }^{17}$ Considering art

${ }^{16}$ Marks G. (2010) Kartinnaya galereya Starye mastera. Shedevry iz Drezdena [Picture gallery Old masters. Masterpieces of Dresden] (trans. Zirmann E.). Leipzig: E. A. Seemann, p. 5.

17 Hegel G. W. F. (1977) Entsiklopediya filosofskikh nauk [Encyclopedia of philosophical sciences] (Vol. 3). Moscow: Mysl', p. 383. 
as a form of knowledge that is higher than scientific knowledge, and irrational and sensual knowledge higher than rational one, Romanticism proved this idea almost to the worship of art. In this discourse, art museum played an extremely important role - to be the "temples of art".

In the book "Heartfelt Outpourings of an Art Loving Monk" by Wilhelm Wackenroder, founder of German Romanticism, the publication of which in 1797 is considered the birth date of German Romanticism, the philosopher wrote: "art gallery is imagined as a fair, while it should be a temple, where in quiet and silent humility, in inspired solitude, a person will admire the majestic of mortals - artists". ${ }^{18}$

Thus, in the early XIX century, under the influence of Romanticism quickly gaining the position of dominant paradigm in the European worldview, the rhetoric of art museum also changed. It was considered as a temple of art (it was said, quite logically, first of all about art museums). The paradox of this metaphor was that while art was sacralized by the Romantics, the understanding of museum as a temple was quite secular. The policy of secularization pursued by Napoleon in the occupied territories of the Italian and German states had its effect. As a result of this Napoleonic reform, Western European museums and galleries were replenished with masterpieces of religious art that had previously been in monasteries and churches.

The worship of art, transformed by ideologists of Romanticism into a fashion trend for most of the XIX century, meant worship of antique and then of folk art. As K. Hudson aptly described that time "be modern means to be interested in antiquities". 19

Gradually, Romanticism became the ideological basis for formation of national states. Due to this, the object of worship was replaced, ranging from antique art to medieval or even pre-Christian. Now Romanticism required knowledge of cultural and historical past of the people turning into a political nation. In the light of this task, the role of museums, including art museums, in determining national identity became one of the most important and came to the fore.

The architectural and spatial visualization of museum as a temple of art was implemented by several European monarchs. The idea of museum as a temple was most clearly embodied by Ludwig I of Bavaria in the so-called Area of arts in the center of Munich.

${ }^{18}$ Hudson K. (2001) Vliyatel'nye muzei [Influential museums] (trans. Motylev L.). Novosibirsk: Sibirskiy khronograf, p. 48.

${ }^{19}$ Hudson K. (2001) Vliyatel'nye muzei [Influential museums] (trans. Motylev L.). Novosibirsk: Sibirskiy khronograf, p. 44. 
Ludwig I represented the center of Munich like an ancient forum. The first building of future Area of art was the Glyptothek (1816-1830) built by the architect Leo von Klenze on the North side of Königsplatz square. The frescoes made by Peter von Cornelius, one of the most famous representatives of German Romanticism, member of Nazarene Brotherhood, adorned the building.

The building for the Royal Collections of Antiquities (now the State Collections of Antiquities) was built during 1838-1848 by the architect Georg Friedrich Ziebland opposite the Glyptothek on the south side. ${ }^{20}$

On the west side, the Königsplatz was closed by Propylaea (1846-1860) built by the architect Leo von Klenze in the style of propylaea of the Acropolis of Athens.

The Ionic, Corinthian and Doric orders were used to give the exterior of all these buildings a resemblance to ancient architecture.

The grandson of Ludwig I, Ludwig II King of Bavaria ("the Fairy Tale King"), who was already interested in national romanticism, visualized his admiration for the Gothic-styled architecture of Neuschwanstein, which, although not a museum, but embodied the concept of a castle-temple of art.

It should be noted that in German lands romanticism was organically merged with enlightening inertia, which proved to be extremely productive for the development of museums in general.

As M. Horkheimer and T. Adorno aptly pointed out: "In Germany, the lack of democratic control spreading over all spheres of life has led to paradoxical results. ... The German education system, including universities, renowned art theaters, large orchestras and museums, enjoyed all sorts of protectionist support. Political forces at the level of state and municipal communities, which inherited these institutions from absolutism, allowed them to maintain that independence from the relations of domination proclaimed by the market, the guarantors of which until the nineteenth century were princes and other feudal lords. In the late phase of art development this circumstance increased the resistance of art to the dictates of mechanism of supply and demand ...". ${ }^{21}$

In Europe, the situation has changed dramatically since the end of the First World War, which led to revolutions and redrawing of states.

20 Wunsche R. (2007) Gliptothek Munich: Masterpieces of Greek and Roman sculpture (trans. Batstone R.). Munich: Beck C. H., pp. 11-12.

21 Horkheimer M., Adomo T. (1997) Dialektika Prosveshcheniya: filosofskie fragmenty [Dialectics of the Enlightenment: Philosophical Fragments] (trans. M. Kuznetsova). Moscow; St. Petersburg: Medium; Juventa, p. 165. 
Romanticism destroyed by the horror of war and disappointment in rationalism-based ideologies led to a rethinking of museum in general and art museum in particular. It no longer seemed like a temple - place of worship for art, and art itself has changed dramatically. Modern art could by no means be the ideal of which Hegel wrote, and could by no means inspire awe. Rather, on the contrary.

The social responsibility of museum at least was questioned, as well as its function of preserving and relaying social and cultural memory. There were questions whether museum is needed and isn't it just a history?

In his best-selling book "The Decline of the West", written during the First World War, Oswald Spengler noted: "And these museums themselves, in which we assemble everything that is left of the corporeally-sensible past! ... Are they not intended to conserve in mummy the entire "body" of cultural development? ... do we not also collect all the works of all the dead Cultures in these myriad halls of West-European cities, in the mass of the collection depriving each individual piece of that instant ... and as if dissolved it into our unending and unresting Time?". 22

In the post-war years, European art museums, as well as museums in general, went through a period of nationalization (the former Russian and Austro-Hungarian empires) and democratization.

Total nationalization of museums and collections took place in Soviet Russia and the USSR. Partial nationalization took place in Austria and Germany and marked the democratization of museums that opened their treasures to mass visits not only by highly educated public. Visiting museums along with other leisure facilities became more and more popular. This, in particular, provided grounds to Spanish philosopher J. Ortega y Gasset to speak about mass character of culture and dehumanization of art. ${ }^{23}$ In the late 20 s and early 30 s, the Soviet art museums were involved in a campaign of mass sale of art treasures. This campaign in the USSR was presented under the slogan of uselessness of "bourgeois" art, which is supposedly hostile to the proletariat, which should create its own, new, "revolutionary" art.

By emptying its own museums, the Soviet government enriched private collections of European businessmen and American magnates, such as Calouste Gulbenkian and Andrew William Mellon, with their masterpieces.

${ }^{22}$ Spengler O. (2009) Zakat Evropy. Ocherki morfologii mirovoy istorii [Sunset of Europe. Essays on the morphology of world history] (trans. Garelin N., vol. 1). Moscow: Eksmo, p. 351.

${ }^{23}$ Ortega y Gasset J. (1994) Vybrani tvory [Selected works] (trans. Burghardt W.). Kyiv: Osnovy, p. 14. 
A. Melon, like the English collector Joseph Duveen, selected paintings by the catalog of P.P. Weiner. As the Hermitage keeper A.A. Trubnikov wrote, the choice of A. Melon was no different from the tastes of other American collectors, "... you should deal with painting that brings up sad thoughts, such as ruin, poverty and death ... Vernet's "Mornings" are always beautiful, but his "Dark evenings" - never, people are afraid of dark canvases". ${ }^{24}$ In total, Andrew Mellon purchased 21 paintings from the Hermitage Art Gallery, including paintings by Raphael, Leonardo da Vinci, Simone Martini, Perugino, Cima da Conegliano, Paolo Veronese, Diego Velazquez, Bartolome Murillo, Jan van Eyck, Peter Paul Rubens, Anthony van Dyck, Pieter de Hooch, Rembrandt, for which the Soviet side received $\$ 6,654,053 .^{25}$

Only in 1929, 219,000 paintings and other art objects from the State Hermitage Museum for 19,422,000 rubles were taken abroad and sold at auctions. In 1930, the number of sales from the Hermitage had already increased to 577,000 works for $27,306,000$ rubles. ${ }^{26}$

At the same time, the USSR considered museum as an institution of education for the masses. This also applied to art museums.

However, in the totalitarian regimes of the USSR and Nazi Germany, art museums very quickly began to play an ideological and propaganda function. The artistic works contradicting certain ideological principles were either sold under the slogan "bourgeois" (sales of the USSR in 1929-1932) or destroyed ("Degenerate art" campaign of 1936-1941 in Germany).

On May 31, 1939, the Law on Confiscation of Products of Degenerate Art was adopted in Germany. In total, 1004 paintings and 3,825 drawings, watercolors and engravings, including those from Dresden, were burned as part of the "Degenerate art" campaign in Berlin, where the confiscated works of fine art were brought. The rest of the confiscated artistic works (which is about 13000) were sold at auctions. The paintings by Erich Heckel, Otto Dix, Ernst Ludwig Kirchner, Oskar Kokoschka, Carl Lohse, Emil Nolde, sculptures by William Wauer, Wilhelm Lehmbruck, Ernesto di Fiori, Eugen Hoffman, and others were prohibited.

${ }^{24}$ Piotrovskiy M. B. (2016) Gosudarstvennyy Ermitazh. Muzeynye rasprodazhi. 1930 1931. Arkhivnye dokumenty [The State Hermitage Museum. Museum sales. 1930-1931. Archival documents]. St. Petersburg: The State Hermitage Publishing House, p. 41.

${ }^{25}$ Piotrovskiy M. B. (2016) Gosudarstvennyy Ermitazh. Muzeynye rasprodazhi. 1930 1931. Arkhivnye dokumenty [The State Hermitage Museum. Museum sales. 1930-1931. Archival documents]. St. Petersburg: The State Hermitage Publishing House, p. 47.

26 Piotrovskiy M. B. (2016) Gosudarstvennyy Ermitazh. Muzeynye rasprodazhi. 1930-1931. Arkhivnye dokumenty [The State Hermitage Museum. Museum sales. 1930 1931. Archival documents]. St. Petersburg: The State Hermitage Publishing House, p. 8. 
50 paintings and about 20 sculptures from the New Masters Gallery, Albertinum, were confiscated, taken and destroyed by the national socialists. $^{27}$

Despite the differences, art museums have become an important propaganda institution in both countries.

While the vast majority of art museums in Europe were of elite origin, that is, European elites (higher clergy and aristocracy) were the driving force for creation of museums, art museums in the United States were often founded by societies or urban communities based on a civic initiative, in which formal and informal communities of artists often played an important role.

Initially, art museums in the United States were intended for educational purposes: training future artists, like University Galleries, for general or educational mission. In the second case, museums, including art museums, became the second school or institute where the child consolidated the knowledge gained in the "first" ones and acquired new knowledge and competencies provided by museum environment.

Thus, Cleveland Museum of Art, which has one of the best art collections in the United States and is one of the largest art museums in Ohio, was founded in 1913 under the slogan "for the benefit of all the people forever". Its first director, Frederic Allen Whiting, believed that museum could operate as an educational institution.

After the First World War, which contributed to the enrichment of a large number of US industrialists, while war-ravished Europe was forced to put masterpieces of art on the art market, art museums are created, the main purpose of which was to become the richest treasury of world art. The mass buying and exporting from different countries, mainly European, not only easel, but also monumental art and even architecture, formed such gigantic art museums, as the Metropolitan Museum of Art in New York that was founded in 1870. And if the XIX century was held mainly under the slogan "art museum is a temple of art", the MET became the embodiment of what could be defined as "art museum is a treasury of art".

As J. Baudrillard aptly said about this situation, there was a "capitalist centralization of values". ${ }^{28}$

After the Second World War, after a rather long period of reconstruction and restoration of destroyed museums and an even longer process of

\footnotetext{
${ }^{27}$ Wagner H. (ed.) (2018) Albertinum: Art from Romanticism to the Present. Dresden: Walther Konig, p. 11.

28 Baudrillard J. (2004) Symuliakry $i$ symuliatsiia [Simulacra and simulations] (electronic book) (trans. Khovkhun V.). Kyiv: Fundamentals. Retrieved from: http://shron1.chtyvo.org.ua/Jean_Baudrillard/Symuliakry_i_symuliatsiia.pdf (accessed 4 December 2020).
} 
restitution of art treasures displaced during the war, there was a period of popularity of art museum visitation that led to a certain museum boom.

The mass culture moved to a new level of development, the specificity of which became the object of theoretical reflection of postmodern philosophy.

As J. Baudrillard wrote about the ecomuseum in the urban community Le Creusot and Montceau-les-Mines (Museum of Man and Industry), "the same thing happens in Creusot, within the museum "in a disassembled form", where the whole working quarters, operating metallurgical zones, at once whole culture, including men, women, children - together with their gestures, manner of speaking, customs - during life turned into fossils, as on the lookout playground, were transformed into museum as "historical" witnesses of their era. Instead of being a geometric point, the museum is now everywhere as a dimension of life". ${ }^{29}$

He continued: "this distribution, regrouping, interference of all cultures, unconditional aestheticization giving the culture the character of hyperreality already began in the traditional museum, but museum is still a memory. In no other place has culture lost so much memory in favor of accumulation and functional redistribution. And this is an expression of a more general fact: that everywhere in the "civilized" world, the creation of stocks of objects has led to an additional process of formation of human stocks, queues, waiting, "traffic jams", concentration and camps. That is a real "mass production", not in terms of production in large quantities or for mass consumption, but in terms of production of masses". 30

However, despite this boom and growth of a peculiar fashion "to go everywhere and see everything with own eyes" (or according to Jean Baudrillard "People have the desire to take everything, to pillage everything, to swallow everything, to manipulate everything"), ${ }^{31}$ tendencies were formed, which became clear at the beginning of the XXI century. They are related to globalization, the cultural realities of which raised a number of questions: what is an art museum in new world, what role it plays in social

${ }^{29}$ Baudrillard J. (2004) Symuliakry i symuliatsiia [Simulacra and simulations] (electronic book) (trans. Khovkhun V.). Kyiv: Fundamentals, p. 15. Retrieved from: http://shron1.chtyvo.org.ua/Jean_Baudrillard/Symuliakry_i_symuliatsiia.pdf (accessed 4 December 2020).

30 Baudrillard J. (2004) Symuliakry i symuliatsiia [Simulacra and simulations] (electronic book) (trans. Khovkhun V.). Kyiv: Fundamentals, p. 102. Retrieved from: http://shron1.chtyvo.org.ua/Jean_Baudrillard/Symuliakry_i_symuliatsiia.pdf (accessed 4 December 2020).

31 Baudrillard J. (2004) Symuliakry i symuliatsiia [Simulacra and simulations] (electronic book) (trans. Khovkhun V.). Kyiv: Fundamentals, p. 104. Retrieved from: http://shron1.chtyvo.org.ua/Jean_Baudrillard/Symuliakry_i_symuliatsiia.pdf (accessed 4 December 2020). 
life, and whether it retains its previous image as a temple/ repository/treasury of artistic values - or its purpose has changed dramatically.

\section{Rethinking the Art Museum}

as a Subject of Social and Cultural Dimension

Modern times caused art museum to realize that previous articulations of its role and social purpose are not relevant.

Even the most successful art museum in the world - the Louvre in Paris, which in 2018 was visited by 10 million 200 thousand visitors, cannot "rest on his laurels". 32

The reason for this "museum turn" is less competition between museums than competition between other mass culture institutions providing leisure and entertainment services.

The competition identified weak points. As a repository of art, it is enough to visit the art museum once or twice, because the past frozen in museum specimens does not change and does not provide a constant novelty of sensations, as do cinemas, concert halls, entertainment centers and sports grounds.

The art museum needed to look at itself "with its own eyes", and, realizing its uniqueness among others, to tell about it "urbi et orbi".

There was an urgent need for marketing activities, therefore, new positioning and development of marketing communication system.

Marketing as market ideology ( $\mathrm{Ph}$. Kotler) proceeds from the basic fundamentals that satisfaction of human needs is its social basis.

By analogy, it should be noted that previous museum discourses, which defined the main social role and purpose of the art museum, were based on the assumption that museum satisfies the need of a person (and society) for knowledge (discourse of Enlightenment) or for aesthetic pleasure (enjoyment of fine art) - discourse of Romanticism.

The discourses of totalitarian political regimes were not interested in human needs, and art museums were given the role of "satisfying" the needs of political elite. Therefore, in fact, museums performed an ideological function, which was closely intertwined with manipulative function, as a function of hidden control of the masses through artistic works.

The discourse of mass culture, the current stage of development of which is characterized by globalized nature, is the discourse of consumption.

32 Louvre (2018) Rapport d`Activite [Activity Report]. Retrieved from: https://www.louvre.fr/sites/default/files/medias/medias_fichiers/fichiers/pdf/louvrerapport-d-activites-2018.pdf (accessed 15 November 2019). 
Spanish philosopher J. Ortega y Gasset was one of the first to draw attention to the phenomenon of mass culture. In his work "The Revolt of the Masses", he wrote that availability of so-called high culture to population masses does not guarantee an increase in the cultural level of the "mass person". ${ }^{33}$ On the contrary, there is a primitivization of art and culture becomes an object of consumption. ${ }^{34}$

Comics are another form of mass culture. Today comics are exhibited in museums of world importance. As French museologist Fabrice Douar writes in the article "Comics: always in the Louvre", the selected comics authors, each in their own way, questioned the part of the cultural reality represented by this organization (Louvre. - O. G.). They played with imaginations that the Louvre collections excite in all visitors. Their choice was guided by two axes of reflection, which can be well seen in the set design of the exhibition by Étienne Davodeau, Enki Bilal, Hirohiko Araki, Nicolas de Crécy, who created bridges between museum and the "Ninth Art" of comics. ${ }^{35}$

According to Ukrainian authors A.V. Muzychenko, N.S. Nazarova and I.A. Stryzhova, "the mass person swallows and consumes everything that society can give them ...". This is how they "consume" the artistic works in art museums, because "in perception of cultural samples, they are not guided by internal needs, but act under the influence of fashion and advertising. There is an endless crowd of visitors clicking their cameras near Mona Lisa in the Louvre. This fixation (with digital camera or video camera of mobile phone) becomes a significant gesture in the space of modern culture. There are other authentic works of Leonardo da Vinci, but people pass them by indifferently". ${ }^{36}$

It should be noted that "fixation of one's stay in the space of modern culture", as a sign gesture of this culture, can be considered as a new need formed by such technical means as camera and mobile phone with a built-in video camera. The latter device made it possible to simultaneously self-fix person and space, for example, against the background of museum specimen. That is known as selfie.

\footnotetext{
${ }^{33}$ Ortega y Gasset J. (1994) Vybrani tvory [Selected works] (trans. Burghardt W.). Kyiv: Osnovy.

${ }^{34}$ Ortega y Gasset J. (1994) Vybrani tvory [Selected works] (trans. Burghardt W.). Kyiv: Osnovy, p. 14.

${ }^{35}$ Douar F. (2016) La bande dessinee: au Louvre depuis toujours [The comic strip: at the Louvre since always]. Grande Galerie [Great Gallery], no. 36, p. 98.

36 Muzychenko A. V., Nazarova N. S., Strizhova I. A. (2014) Obshchestvo potrebleniya $v$ epokhu globalizatsii: sotsial'no-politicheskie aspekty [Consumer society in the era of globalization: socio-political aspects]. Odessa: Vydavnychyi dim.
} 
Selfie as a phenomenon of highly technological culture is poorly studied. In our opinion, it is a modern form of expression of the need for selfaffirmation and social recognition. A kind of modern analogue of the graffiti carved on park benches or scratched on the walls: "I was here".

This is just one of the new human needs that art museums will have to reckon with, especially taking into account the fact that amateur photography is forbidden in the vast majority of them.

But this is not the only thing that edits the practice of museum work with visitors.

The strategic innovation is that art museum will have to distance itself from the rhetoric of "flashback".

If in the Age of Romanticism the past was sacralized ("be modern means to be interested in antiquities" (K. Hudson), now the future is sacralized. The word "future" has an exceptionally positive connotation, symbolizing more progressive, more developed and, implicitly, something happier. Museum should be associated with this positive. According to Jean-Luc Martinez, director of the Louvre, today even the Louvre presents itself to the world under the slogan: "The Louvre: An Age-Old Institution that Looks to the Future". ${ }^{37}$

However, it is not enough for the vast majority of art museums to change their rhetoric by saying that they "travel to the future". Therefore, the tasks of art museums, especially those that are not located at the intersection of global flows of visitors, like the Louvre, are somewhat different. They are tasked with updating or even forming a new need to visit an art museum.

Therefore, the communicative function of art museums suggesting their own vision of what a museum can give to humanity, certain community or individual today is brought to the forefront. The art museum is tasked with articulating its social mission according to the needs of modern person, one of which, as the selfie shows, is the need for self-expression through "fixing one's stay in the space of modern culture".

The Wadsworth Atheneum, art museum in Hartford (Connecticut, USA), considered the above need when searching for their own positioning in new social and cultural environment.

The Wadsworth Atheneum is the first public art museum in the United States. It was founded in 1842 by philanthropist Daniel Wadsworth and opened to the public in 1844. Currently, the Wadsworth Atheneum, whose collection is characterized by an encyclopedic nature, preserves 50,000 pieces of art.

37 Martinez J.-L. (n.d.). Missions et projets. Louvre. Retrieved from: https://www.louvre.fr/missions-et-projets (accessed 6 November 2020). 
In particular, the collection of European art includes 900 paintings, 500 sculptures and 3,500 works of graphic art from the middle ages to the present; the collection of American art has about 1,000 paintings, 400 sculptures and 4,000 pieces of graphics; the collection of European decorative art has about 7,000 objects.

The museum also displays the collection of paintings, drawings, sketches and costumes for ballet productions by Sergei Diaghilev's group. There is also a unique collection of firearms by gun magnate Samuel Colt, a native of Hartford, acquired in 1905 from his widow Elizabeth Hart Jarvis Colt.

Despite the remarkable art collection, the Wadsworth Atheneum was tasked with increasing the attendance of museum.

The traditional methods did not have much effect, because even wonderful collections can be viewed once or twice and no longer feel the need to visit the museum.

In 2012, the Wadsworth Atheneum developed and implemented the Collaborative Gallery project. ${ }^{38}$ The essence of the project was as follows. Mini exhibitions were created in several museum rooms: room of still life, room of installations, etc. The main idea was not in the museum specimens exhibited there, but in the fact that the visitors could take part in formation of the exhibition in these rooms. In the room of still life they had the opportunity to draw their own still life. In another room they could make an installation. They could write their thoughts about design, theme, possible sections and collections, and locations. They also could offer a self-made artifact as an exhibit, explaining why it deserves to be included in the gallery exhibit. The comments, ratings and notes were "stitched" to macro notepads that were placed in the appropriate rooms. They could be viewed, read and added by your thoughts and impressions.

The developers of the idea assumed that visitors of gallery wanted to express themselves, and the project was successful. Providing an opportunity to meet this need, the museum turned from a repository of artistic works into a space of interpretation in which visitors gave their own meanings to artifacts and created their own content inspired by museum specimens.

The project allowed articulating the vision of social mission of the Wadsworth Atheneum. As some visitors participated in the project several times, it became clear that the museum target audience is primarily residents of Hartford. In order for them to become regular museum visitors, and not limited to one or two visits necessary to get acquainted with the exhibits, the museum introduced daily free entrance for city residents. In other words, it turned itself into a cultural space for communication and self-expression.

\footnotetext{
${ }^{38}$ Simon N. (2010) The Participatory Museum. Santa Crus: Museum 2.0.
} 
The new slogan of the Wadsworth Atheneum was "Museum belongs to its neighbors". The neighbors are residents of Hartford, and the Wadsworth Atheneum is a vital part of the city where residents come together to "feel the power of art".

The Baltimore Museum of Art (Baltimore, Maryland) is another art museum positioning itself as part of a citywide cultural space.

The Baltimore Museum of Art has one of the most interesting collections in the United States. Today, the museum's collection includes about 95,000 artistic works spanning the period from the Renaissance to the XX century, and contains paintings, sculptures and works of applied art.

Some of them are unique. Thus, the collection of works by Henri Matisse of more than 1000 works is the largest in the world.

The decoration of the BMA collection is the works of Louis Comfort Tiffany, notable American Art Nouveau artist, that are part of the American collection of the museum, which has more than 800 artistic works.

The collection of dozens of ancient mosaics from Antioch (I-V centuries $\mathrm{AD}$ ) appeared in the museum due to its participation in archaeological excavations that were conducted in the 1930s in Syria and Turkey together with Worcester Art Museum (Massachusetts), Princeton University (New Jersey) and the Louvre (France). It is now a unique collection that turns BMA into one of the most famous art museums in the world.

Despite this, the museum had to change its positioning. This resulted in active participation in the program under the slogan "We cover the brilliance of Baltimore", along with other cultural and leisure institutions of city. ${ }^{39}$ It should be noted that, unlike the European museums, American art museums, responding more flexibly to new challenges, focus not on the museum, that is, on their interests and needs, but on visitors.

The Denver Art Museum is another example of changing museum rhetoric. Founded in 1893, the Denver Art Museum has one of the largest art collections in the United States.

The museum has more than 70,000 exhibits. In addition to collections of European and American art, the museum has collections of African, Asian and colonial Spanish art (one of the most representative in the United States and one of the best in the world). The American Indian art collection (ancient Puebloan ceramics and Navajo textiles) is the pride of the museum, as this museum was the first to collect and study artifacts of American Indian art. This collection is now the largest in the world and has more than 16,000 items.

${ }^{39}$ Simon N. (2010) The Participatory Museum. Santa Crus: Museum 2.0, pp. 42-43. 
In the early 1950s, the Denver Art Museum opened a center of art activities for kids, thanks to which it has become a leader in educational programs over the past decades.

Working with kids and teenagers allowed the museum to better understand the age psychology of these groups and better understand their needs, the most important of which are the need for mutual entertainment and communication.

These assumptions were extrapolated to an adult audience as well. For example, the Denver Art Museum held a successful program inspired by an exhibition of Side Trip posters dedicated to rock music. The visitors were invited to share their memories of attending rock concerts, as well as to create their own posters dedicated to rock music. With permission of their authors, the posters were displayed allowing visitors to see their work on the screen and feel like artists. ${ }^{40}$

The interpersonal communication on this newsworthy event provided by the museum, sharing the experience of music lovers contributed to growing popularity of the Denver Art Museum.

The direct communication with its visitors as a principle of modern museum discourse is used in the museums of the Smithsonian Institution one of the largest museum groups in the world.

The Smithsonian Institution was founded by a special resolution of the United States Congress in 1846. The museum is named after famous British scientist James Smithson, who bequeathed \$ 5 million, his library and collection of minerals to the United States of America, even though he has never been to the United States. Smithson bequeathed these funds and collections "for the increase and diffusion of knowledge" among young American nation. The social mission of the Smithsonian Institution from the very beginning was seen as educational one.

The museum group of the Smithsonian Institution has a separate unit for the artistic communication of African-Americans who come here with whole family in order to strengthen their identity and pass the cultural traditions of their families and regions of origin on their children.

In 2009, the Institution's National Art Gallery implemented the Fill the Gap project, in which visitors were encouraged to create their own artistic work that they thought could be placed in the Gallery. It could be photo, video, picture, installation, etc. The project allowed the Gallery to "turn into a group public experience of creating an art artifact". ${ }^{41}$

As noted by American museologist Prerana Reddy, projects of the Queens Museum in New York, exhibitions organized by the museum

\footnotetext{
${ }^{40}$ Simon N. (2010) The Participatory Museum. Santa Crus: Museum 2.0, p. 23.

${ }^{41}$ Simon N. (2010) The Participatory Museum. Santa Crus: Museum 2.0, pp. 150-151.
} 
covered the art and experience of local immigrant societies "Binding Thread: Taiwan in Queens", biennale "International Queens: Crossing the Boulevard" (its participants were artists who live in Queens), multimedia project by Warren Lehrer and Judith Sloan based on oral stories of new immigrants and refugees who settled in Queens. ${ }^{42}$ Using the arts as a powerful communication resource, we provided young participants in projects and programs with skills and tools necessary to navigate the civic and educational structures of America. ${ }^{43}$

A similar project was implemented by one of the largest art museums in the United States - Brooklyn Museum of Art. The Brooklyn Museum of Art is considered the second largest art museum in New York and one of the largest and oldest in the United States. Its formation dates back to 1823 when the library of the Brooklyn Commercial School was founded. The museum's collection includes more than one and a half million exhibits representing the art of almost all world cultures and eras: from ancient Egypt to modern times.

The museum's ancient Egyptian collection is considered one of the largest and best not only in the United States, but also in the world, and contains unique papyri and sculptures that were found during excavations of the temple in Karnak. Between 1906 and 1908, the museum sponsored an expedition that conducted excavations in southern Egypt and Nubia. As a result of expeditions, museum got a significant part of the material from the excavations, and it received items of significant historical and cultural value. Since 1976, the Brooklyn Museum has also conducted archaeological excavations at the Temple of the Goddess Mut in Karnak.

Despite the uniqueness of some of the collections in the museum collection and their number, the Brooklyn Art Museum also required increasing number of visitors and securing their loyalty to the museum.

The purpose of project of the Brooklyn Museum of Art was to find out how the "crowd" is able to "wisely" make judgments about art. The photo contest "The Changing Face of Brooklyn" was announced. The photos were posted on the site, selected for the exhibition and exhibited.

${ }^{42}$ Agapova D. (ed.) (2015) Kul'tura uchastiya: muzey kak prostranstvo dialoga $i$ sotrudnichestva [Participatory Culture: Museum as a Forum for Dialogue and Collaboration] (electronic book). St. Petersburg, p. 36. http://kizhi.karelia.ru/media/info/files/attached/1601/kultura_uchastiya_muzej_kak_prost ranstvo_dialoga_i_sotrudnichestva.pdf (accessed 5 December 2020)

${ }_{43}$ Agapova D. (ed.) (2015) Kul'tura uchastiya: muzey kak prostranstvo dialoga $i$ sotrudnichestva [Participatory Culture: Museum as a Forum for Dialogue and Collaboration] (electronic book). St. Petersburg, p. 38. http://kizhi.karelia.ru/media/info/files/attached/1601/kultura_uchastiya__muzej_kak_prost ranstvo_dialoga_i_sotrudnichestva.pdf (accessed 5 December 2020). 
The sense of involvement in the process of artistic creation, and, accordingly, increase in self-esteem and pleasure of realization in selfaffirmation, contributed to the formation of an attracted environment around the museum. The social mission should be articulated as mission of the public museum.

\section{CONCLUSION}

Since its institutionalization, the rethinking the art museum has evolved from the verbalization of its perception as educational institution and "temple of art" to the articulation of self-presentation as cultural space and social communication platform that inspires a discourse in which museum visitors create their own art.

By the end of the XX century, the art museum "perceived itself" according to the external idea of its role and purpose. It was either as an institution of non-institutional education, or as a temple where works of fine art are reverently viewed, or as a repository of artistic works from which a general educational project is created.

Nowadays, realization of the fact that art museums are not only repositories of artistic works and keepers of artistic and cultural memory of mankind, has led to a shift of emphasis from a purely expositional function, which traditionally provided the attractiveness of these institutions, to a communicative function, function of ensuring cultural identification and self-expression of museum visitors.

In the XXI century, art museums are moving to organization of museum communication based on social network design, which provides feedback to visitors and allows them to share their thoughts and impressions, they become a platform where participants create their content inspired by visit to the museum. The pleasure that art museum can provide to visitors becomes a criterion for the effectiveness of its traditional functions.

Coming of the museum's communicative function to the forefront means that art museum is not only a place for storing, studying, restoring and exhibiting artistic works, but also an institution that provides the multifunctional needs of modern person: determining their place in the global world through museum specimens, mediated communication with the past and modern achievements of mankind embodied in artistic works.

Thus, the rethinking the art museum presentation as an institute of education and "temple of arts" changed to the rhetoric of self-presentation as a locus of the cultural space in which modern person meets the needs for self-realization, as well as social and cultural communication.

\section{SUMMARY}

The purpose and social role of public art museum at the beginning of its institutionalization were determined according to the worldview and 
philosophical paradigms of a specific historical and cultural era. The rethinking the role and purpose of art museum was determined by external social and cultural intellectual and political environment of the museum. Nowadays, art museums formulate their own vision of their role and directions of development, realizing their social mission and vision of their own future, in one way or another imagining themselves as "urbi et orbi". To investigate changes in rhetoric of art museum as an object of social and cultural discourse and to identify features of rhetoric of art museum as a subject of social and cultural discourse in modern globalized culture. The ranges of cultural methods, method of social and philosophical analysis, systematic approach were used. The historical and cultural analysis of changes in rhetoric of art museum as an object of social and cultural discourse from the Age of Enlightenment to the rhetoric of art museum as a subject of social and cultural discourse in modern globalized culture. The evolution of art museum rhetoric from the articulation of its perception as educational institution and "temple of art" to the articulation of selfpresentation as cultural space and social communication platform is determined. The art museums are moving to organization of museum communication based on social network design, which provides feedback to visitors and allows them to share their thoughts and impressions, providing the museum with the role of permanent newsmaker and platform where participants create the discourse inspired by visit to the museum. During the study period, the rethinking the art museum presentation as an institute of education and "temple of arts" changed to the rhetoric of self-presentation as a locus of the cultural space in which modern person meets the needs for self-realization, as well as social and cultural communication.

\section{REFERENCES}

1. Agapova D. (ed.) (2015) Kul'tura uchastiya: muzey kak prostranstvo dialoga $i$ sotrudnichestva [Participatory Culture: Museum as a Forum for Dialogue and Collaboration] (electronic book). St. Petersburg. http://kizhi.karelia.ru/media/info/files/attached/1601/kultura_uchastiya_mu zej_kak_prostranstvo_dialoga_i_sotrudnichestva.pdf (accessed 5 December 2020). (in Russian)

2. Baudrillard J. (2004) Symuliakry $i$ symuliatsiia [Simulacra and simulations] (electronic book) (trans. Khovkhun V.). Kyiv: Fundamentals. Retrieved from: http://shron1.chtyvo.org.ua/Jean_Baudrillard/Symuliakry_ i_symuliatsiia.pdf (accessed 4 December 2020). (in Ukrainian).

3. Bel'kevich D. (2012) Muzey v poiskakh auditorii [Museum in search of an audience.]. Iskusstvo [Art] (electronic journal), no. 2(581). Retrieved from: http://iskusstvo-info.ru/muzej-v-poiskah-auditorii/ (accessed 5 December 2020). 
4. Douar F. (2016) La bande dessinee: au Louvre depuis toujours [The comic strip: at the Louvre since always]. Grande Galerie [Great Gallery], no. 36 , p. 98 .

5. Falk J. H., Dierking L. D., Adams M. (2006) Living in a learning society: museums and free-choice learning. A Companion to Museum Studies (ed. Macdonald S.). Padstow: Blackwell Publishing, pp. 323-339.

6. Fossi G. (2017) Galereya Uffitsi. Ikusstvo, istoriya, kollektsii [Uffizi Gallery. Art, history, collections]. Florence: Giunti Editore. (in Russian)

7. Goncharova O. M. (2018) Kulturni praktyky dlia ditei u khudozhnikh muzeiakh SShA [Cultural practices for children in the USA Art Museums]. National Academy of Managerial Staff of Culture and Arts Herald, no. 1, pp. 16-20.

8. Goncharova O. M. (2018) Muzeini praktyky dlia ditei v khudozhnikh muzeiakh Federatyvnoi Respubliky Nimechchyny [The German Federal Republic (Bundesrepublik Deutschland) Art Museums' practices for children]. National Academy of Managerial Staff of Culture and Arts Herald, no. 4. pp. 29-35.

9. Grabill J. T., Pigg S., Wittenauer K. (2009) Take Two: A Study of the Co-Creation of Knowledge on Museum 2.0 Sites. Proceedings of the Museums and the Web 2009: the international conference for culture and heritage online. (April 15-18, 2009). http://www.museumsandtheweb.com/ mw2009/papers/grabill/grabill.html (accessed 5 December 2020).

10. Hegel G. W. F. (1977) Entsiklopediya filosofskikh nauk [Encyclopedia of philosophical sciences] (Vol. 3). Moscow: Mysl'. (in Russian)

11. Hooper-Greenhill E. (2012) Changing values in the Art Museums: Rethinking communication and learning (ed. Carbonell B. M.). Museum Studies: An Anthology of Contexts (2nd ed, pp. 517-532). Malden: Blackwell Publishing.

12. Horkheimer M., Adomo T. (1997) Dialektika Prosveshcheniya: filosofskie fragmenty [Dialectics of the Enlightenment: Philosophical Fragments] (trans. M. Kuznetsova). Moscow; St. Petersburg: Medium; Juventa. (in Russian)

13. Hudson K. (2001) Vliyatel'nye muzei [Influential museums] (trans. Motylev L.). Novosibirsk: Sibirskiy khronograf. (in Russian)

14. Kant I. (1966) Sochineniya [Essays] (Vol. 6). Moscow: Mysl'. (in Russian)

15. Kopelyanskaya N. (ed.) (2015) Muzey kak prostranstvo obrazovaniya: igra, dialog, kul'tura uchastiya [Museum as a space of education: game, dialogue, culture of participation] (2nd ed). Moscow: Muzeinye resheniia. (in Russian) 
16. Louvre (2012) Ves' Luvr. Shedevry, istoriya dvortsa, arkhitektura [All the Louvre. Masterpieces, the history of the palace, the architecture]. Paris: Beaux Arts Editions. (in Russian)

17. Louvre (2018) Rapport d`Activite [Activity Report]. Retrieved from: https://www.louvre.fr/sites/default/files/medias/medias_fichiers/fichiers/pdf/ louvre-rapport-d-activites-2018.pdf (accessed 15 November 2019).

18. Luke J. J., Letourneau S. M., Rivera N. R., Brahms L., May S. (2017) Play and Children's Museums: A Path Forward or a Point of Tension? Curator the Museum Journal, vol. 60, no. 1, pp. 37-46.

19. Marks G. (2010) Kartinnaya galereya Starye mastera. Shedevry iz Drezdena [Picture gallery Old masters. Masterpieces of Dresden] (trans. Zirmann E.). Leipzig: E. A. Seemann. (in Russian)

20. Martinez J.-L. (n.d.) Missions et projets. Louvre. Retrieved from: https://www.louvre.fr/missions-et-projets (accessed 6 November 2020).

21. Muzychenko A. V., Nazarova N. S., Strizhova I. A. (2014) Obshchestvo potrebleniya $v$ epokhu globalizatsii: sotsial'no-politicheskie aspekty [Consumer society in the era of globalization: socio-political aspects]. Odessa: Vydavnychyi dim. (in Russian)

22. Ortega y Gasset J. (1994) Vybrani tvory [Selected works] (trans. Burghardt W.). Kyiv: Osnovy. (in Ukrainian)

23. Piotrovskiy M. B. (2016) Gosudarstvennyy Ermitazh. Muzeynye rasprodazhi. 1930-1931. Arkhivnye dokumenty [The State Hermitage Museum. Museum sales. 1930-1931. Archival documents]. St. Petersburg: The State Hermitage Publishing House. (in Russian)

24. Simon N. (2010) The Participatory Museum. Santa Crus: Museum 2.0.

25. Spengler O. (2009) Zakat Evropy. Ocherki morfologii mirovoy istorii [Sunset of Europe. Essays on the morphology of world history] (trans. Garelin N., vol. 1). Moscow: Eksmo. (in Russian)

26. Wagner H. (ed.) (2018) Albertinum: Art from Romanticism to the Present. Dresden: Walther Konig.

27. Wunsche R. (2007) Gliptothek Munich: Masterpieces of Greek and Roman sculpture (trans. Batstone R.). Munich: Beck C. H.

Information about the author: Goncharova Olena orcid.org/0000-0002-8649-9361 Doctor of Science in Cultural Studies, Professor Kyiv National University of Culture and Arts 36, Ye. Konovaltsia St., Kyiv, 01133, Ukraine 